\title{
Road improvement from flexible pavement to rigid on Munjul - Panimbang Road Banten
}

\author{
Telly Rosdiyani ${ }^{1, *}$, Gunawan Noor $^{1}$, and Irja Iswan ${ }^{1}$ \\ ${ }^{1}$ Civil Engineering Department, Banten Jaya University, Serang City Banten, Indonesia
}

\begin{abstract}
Roads are an important element in promoting public welfare. With the approach of regional development, the achievement of balance and equitable regional development. MunjulPanimbang Road Section, a crossroads of tourist access and liaison between villages and subdistricts, this certainly requires an increase in roads in facilitating transportation mobility. Improving the pavement structure that has been declining is one of the solutions that must be done immediately by replacing the pavement flexure structure into concrete pavement (Rigit Pavement). This project has been completed, thereby analyzing the suitability of the Concrete Pavement Road Pavement Planning. This road improvement uses the Concrete Pavement Concatenated Pavement (BBDT) type, stretching the thickness of concrete plate and the required reinforcement diameter. The research method based on Concrete Pavement Concrete Pavement Planning, Pd T-14 2003. Primary data and secondary data are needed as supporting in research. The result of the analysis shows that concrete pavement planning is $15 \mathrm{~cm}$ thick concrete plaster and perforated reinforcement per meter using 5D15 mm - $200 \mathrm{~mm}$, while crosslinks per meter of 2D10 mm - 500 $\mathrm{mm}$ can withstand the burden of vehicles traveling on the road with the age of 20 years.
\end{abstract}

\section{Introduction}

Road is one of the transportation infrastructure that makes it as an important element in promoting public welfare [1]. With the regional development approach, the achievement of regional development balance and equity, in the economic, social, political and cultural sectors [2,3]. The Munjul-Panimbang Road Section, a crossing of tourist access and links between villages and sub-districts, of course, requires an improvement in the way to facilitate transportation mobility. The lag behind development made Banten have to improve to pursue and equate the situation of other regions to accelerate development to make Banten superior.

The Munjul - Panimbang Road Section is located in Pandeglang Regency, which is a tourist road crossing and industrial area. The age of the Munjul-Panimbang road segment has been old enough, that the condition of the structure decrease in term of flexible road pavement, the growth of traffic in tandem with the growth of population is quite dense optimaly, of course it makes the increase in ownership of vehicles passing on the road. The number of vehicles passing on the road with various types of vehicles required the selection of the right type of pavement to be able to withstand the burden of passing vehicles [4], so that road users can pass smoothly without obstacles. Under these conditions, rigid pavement becomes the choice in increasing the road in the section. The road

\footnotetext{
* Corresponding author: tellyrosdiyani004@gmail.com
}

improvement with rigid road pavements is reflected determine the thickness of the rigid pavement in order to be able to withstand the load of vehicles passing on the road section, as well as to determine the diameter of the reinforcement required in the construction.

\section{Research method}

\subsection{Research site}

The location of the study was carried out on the Munjul Panimbang Street Section of Pandeglang Regency, Banten Province

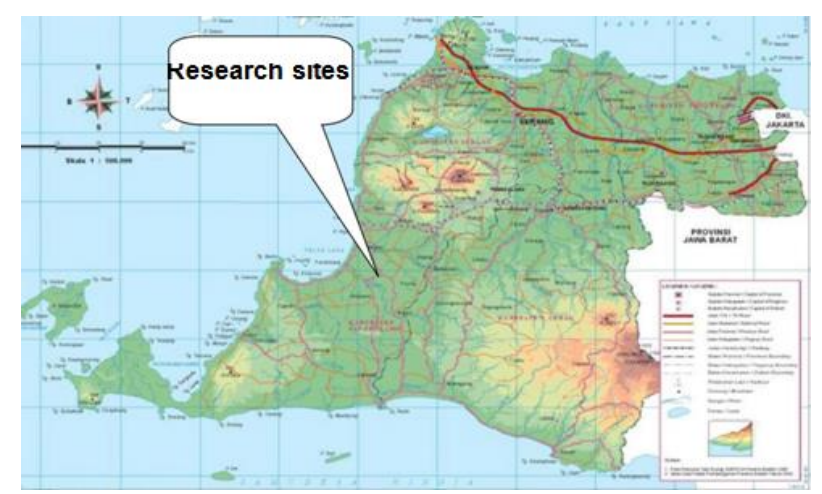

Fig. 1. Location map 
(Source: Department of highways and spatial Banten Province)

\subsection{Data collection technique}

The planning of rigid pavement road in MunjulPanimbang Banten road requires data to be processed as a reference for determining the pavement thickness and diameter of the concrete slab reinforcement to support the load of vehicles passing through the section. The data collection techniques are carried out in the following ways [5]:

\subsubsection{Literature Study}

This is the way to collect secondary data to get the support of theories, documents, and relevant reference materials to researchers needs.

\subsubsection{Interview}

This is by interviewing reliable sources

\subsubsection{Primary Data}

This the way that the data is taken directly from the object under study consists of traffic data and results of interviews data from assistants the Technical Implementation Activities (PPTK) Department of Highways and Spatial Planning Banten Province

\subsubsection{Secondary Data}

This is data taken by researchers indirectly to measure the object of the researcher. It consists of map locatio, $\mathrm{CBR}$ value and etc.

\subsubsection{Observation}

This is the data obtained directly by visiting in the field, this is done at stages research preparation to determine the location of the study and identify the problem of field conditions

\subsubsection{Literatur / reference book}

This is the data obtained from reference books, NSPM (Standard Guidelines and Manual Norms) regarding research themes.

\subsection{Analysis Method}

Road Improvement on Munjul-Panimbang Road Section using rigid pavement, the target of planning is to determine the thickness and diameter of the reinforcement in order to be able to withstand the load of vehicles passing on the road. The planning process is shown in Figure 2. The results of the calculation process can be checked for patric damage analysis and erosion damage if the damage is less than $100 \%$ then the planning results are good and if it exceeds $100 \%$ the design of the plate thickness must be reviewed [6].

This is based on Pd T14-2003 which is shown in Figure 3 on the next page
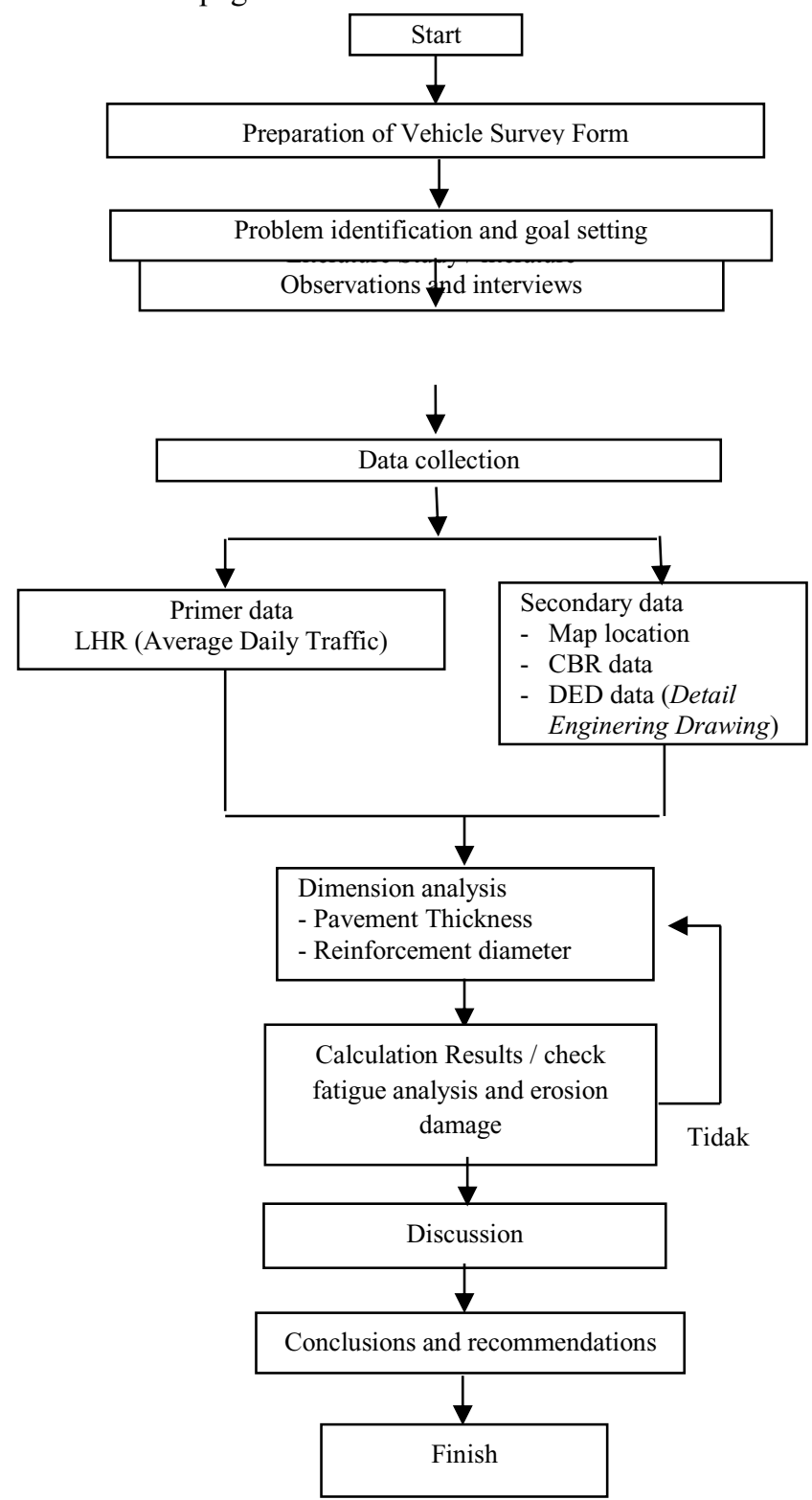

Fig. 2. Research flow chart

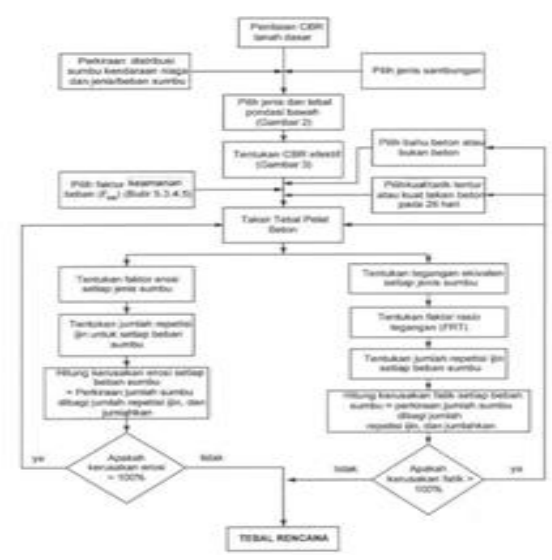

Fig. 3. Concrete pavement planning system (Source: Pd-T14-2003) 


\section{Results and Discussion}

\subsection{Plate Thickness Calculation}

Planning improvement of roads with rigid pavement on the Munjul-Panimbang road requires data including survey data. Rough traffic survey data can be obtained by calculating the volume of vehicles passing on the road for four hours, carried out on weekdays to represent another day showing the fluctuation of the vehicle.

Table 1. Total vehicle amount data

\begin{tabular}{|c|c|c|c|}
\hline \multirow{2}{*}{} & \multicolumn{3}{|c|}{ Light Vehicle } \\
\cline { 2 - 4 } & $\begin{array}{c}\text { Minibus } \\
\text { Sedan } \\
\text { Car, } \\
\text { Jeep }\end{array}$ & $\begin{array}{c}\text { Pick } \\
\text { Up }\end{array}$ & $\begin{array}{c}\text { Small } \\
\text { Truck } \\
\text { 2As }\end{array}$ \\
\hline $\begin{array}{c}\text { 2A } \\
\text { hours }\end{array}$ & 247 & 25 & 28 \\
\hline VJP & $\mathbf{6 2}$ & $\mathbf{6}$ & $\mathbf{7}$ \\
\hline
\end{tabular}

\begin{tabular}{|c|c|c|c|}
\hline \multirow{2}{*}{} & \multicolumn{3}{|c|}{ Heavy vehicle } \\
\cline { 2 - 4 } & Bus & $\begin{array}{c}\text { Big truck } \\
\text { 2As }\end{array}$ & $\begin{array}{c}\text { Truck } \\
\text { 3As }\end{array}$ \\
\hline $\begin{array}{c}4 \\
\text { hours }\end{array}$ & 18 & 13 & 5 \\
\hline VJP & $\mathbf{4}$ & $\mathbf{3}$ & $\mathbf{1}$ \\
\hline
\end{tabular}

(Source: Survey Results)

Based on Table 1 it can be seen that the number of vehicles that will cross a road section for 1 hour planning are minibus sedans, jeeps at most of the other vehicles are 62 vehicles.

$\begin{array}{ll}\text { Load Data Sources } & \text { : Survey Results } \\ \text { Pavement Type } & \text { : BBDT } \\ \text { Shoulder Type } & : \text { Concrete } \\ \text { Plan Age } & : 20 \text { Years } \\ \text { JSK } & : 0.75 \times 105 \\ \text { Load Safety Factor } & : 1.0 \\ \text { Concrete Tensile Strength (fct) Age } 28 \text { days: } 4.0 \text { Mpa } \\ \text { Subgrade CBR } & : 4 \% \\ \text { Effective CBR } & : 27 \%\end{array}$

Table 2. Vehicle amount recapitulation and load configuration

\begin{tabular}{|c|c|c|c|c|c|c|}
\hline \multirow{3}{*}{$\begin{array}{l}\mathbf{N} \\
\mathbf{0}\end{array}$} & & & & \multirow{3}{*}{$\begin{array}{c}\text { No. } \\
\text { of } \\
\text { Veh } \\
\text { icle } \\
\text { s } \\
\text { (bh) }\end{array}$} & \multirow{3}{*}{$\begin{array}{c}\text { No. } \\
\text { of } \\
\text { Axe } \\
\text { s/ve } \\
\text { hicl } \\
\text { e } \\
\text { (bh) }\end{array}$} & \multirow{3}{*}{$\begin{array}{l}\text { No. } \\
\text { of } \\
\text { Axes } \\
\text { (bh) }\end{array}$} \\
\hline & \multirow[t]{2}{*}{$\begin{array}{c}\text { Type } \\
\text { transport }\end{array}$} & \multicolumn{2}{|c|}{$\begin{array}{c}\text { Axis } \\
\text { Load } \\
\text { Configur } \\
\text { ation } \\
\text { (tons) }\end{array}$} & & & \\
\hline & & RD & RB & & & \\
\hline (1) & (2) & \multicolumn{2}{|c|}{ (3) } & (4) & (5) & (6) \\
\hline 1 & MP 2 Tons & 1 & 1 & 272 & & \\
\hline 2 & Bus 8 Tons & 3 & 5 & 18 & & 36 \\
\hline 3 & $\begin{array}{l}2 \text { As Truck } \\
\text { small } 6 \\
\text { Tons } \\
\end{array}$ & 2 & 4 & 28 & & 56 \\
\hline 4 & $\begin{array}{l}\text { 2As Truck } \\
\text { Big } 13 \\
\text { Tons }\end{array}$ & 5 & 8 & 13 & & 26 \\
\hline 5 & $\begin{array}{l}3 \text { As Truck } \\
\text { Td } 20 \text { Tons }\end{array}$ & 6 & 14 & 5 & & 10 \\
\hline 6 & \multicolumn{5}{|c|}{ Total } & 128 \\
\hline
\end{tabular}

\begin{tabular}{|c|c|c|c|c|c|c|}
\hline \multirow{2}{*}{ Type } & \multicolumn{2}{|c|}{ STRT } & \multicolumn{2}{c|}{ STRG } & \multicolumn{2}{c|}{ STdRG } \\
\cline { 2 - 7 } & BS & JS & BS & JS & BS & JS \\
\cline { 2 - 7 } & $\mathbf{( 7 )}$ & $\mathbf{( 8 )}$ & $\mathbf{( 9 )}$ & $\mathbf{( 1 0 )}$ & $\mathbf{( 1 1 )}$ & $\mathbf{( 1 2 )}$ \\
\hline & & & & & & \\
\hline Bus 8 Tons & 3 & 18 & 5 & 18 & & \\
\hline $\begin{array}{c}2 \text { As Truck } \\
\text { small 6 } \\
\text { Tons }\end{array}$ & 2 & 28 & & & & \\
\hline $\begin{array}{c}\text { 2As Truck } \\
\text { Big 13 } \\
\text { Tons }\end{array}$ & 4 & 28 & & & & \\
\hline $\begin{array}{c}\text { 2As Truck } \\
\text { Big 13 } \\
\text { Tons }\end{array}$ & 5 & 13 & 8 & 13 & & \\
\hline $\begin{array}{c}\text { 3 As Truck } \\
\text { Td 20 Tons }\end{array}$ & 6 & 5 & & & 14 & 5 \\
\hline Total & $\mathbf{9 2}$ & & $\mathbf{3 1}$ & & $\mathbf{5}$ & \\
\hline
\end{tabular}

Source: Analysis Results

Where:

$\mathrm{RD}=$ Roda Depan $/$ Front $\quad$ STRT $=$ Sumbu Tunggal wheel Roda Tunggal / Single $\mathrm{RB}=$ Roda Belakang / Wheel Single Axis

Rear Wheel

BS = Beban Sumbu /

Axis Load

JS = Jumlah Sumbu /

Number of Axes

STRG $=$ Sumbu Tunggal

Roda Ganda / Double Wheel Single Axis STDRG $=$ Sumbu Tandem Roda Ganda / Double Wheel Tandem Axis

Number of Commercial Vehicle Axis (JSKN) during the plan life:

$$
\begin{aligned}
\mathrm{JSKN} & =365 \times \mathrm{JSKNH} \times \mathrm{R} \\
& =1.5 \times 10^{5}
\end{aligned}
$$


Where :

JSKN is the Number of Commercial Vehicle Axis

$\mathrm{R}$ is the growth rate. For 5\% in the table Factor of Traffic Growth in the Pd T-14 2003 guidelines, 33.07 was obtained by interpolasi while the JSKN plan was obtained for:

$$
\text { JSKN Plan }=\text { CxR xJSKNH x } 365
$$

Where the table is shown as follows:

Table 3. Number of lines based on the commercial vehicle distribution coefficient

\begin{tabular}{|l|c|c|c|}
\hline \multirow{2}{*}{ Pavement Width } & $\sum^{\sum}$ & \multicolumn{2}{|c|}{$\begin{array}{l}\text { Commercial } \\
\text { Vehicles }\end{array}$} \\
\cline { 3 - 4 } & lane & $\begin{array}{l}\mathbf{1} \\
\text { Directio } \\
\mathbf{n}\end{array}$ & $\begin{array}{l}\mathbf{2} \\
\text { Directio } \\
\mathbf{n}\end{array}$ \\
\hline$<5,5 \mathrm{~m}$ & 1 & 1 & 1 \\
\hline $5,5 \mathrm{~m}<\mathrm{Lp}<8,25 \mathrm{~m}$ & 2 & 0,70 & $\mathbf{0 , 5}$ \\
\hline $8,25 \mathrm{~m}<\mathrm{Lp}<11,25 \mathrm{~m}$ & 3 & 0,50 & 0,475 \\
\hline $11,23 \mathrm{~m}<\mathrm{Lp}<15,00 \mathrm{~m}$ & 4 & - & 0,45 \\
\hline $15,00<\mathrm{Lp}<22,00 \mathrm{~m}$ & 5 & - & 0,425 \\
\hline $18,75 \mathrm{~m}<\mathrm{Lp}<22,00 \mathrm{~m}$ & 6 & - & 0,40 \\
\hline & & & \\
\hline
\end{tabular}

Source: Pd-T14-2003

Based on Table 3 Rigid on Munjul - Panimbang Road Banten has a road width 6 meter so that number of lines based on the commercial vehicle distribution coefficient 0,5 .

Table 4. Factor of traffic growth

\begin{tabular}{|c|c|c|c|}
\hline $\begin{array}{l}\text { Age of } \\
\text { Plan } \\
\text { (Year) }\end{array}$ & \multicolumn{3}{|c|}{ Growth Rate (i) Yearly (\%) } \\
\hline & 0 & 2 & 4 \\
\hline 5 & 5 & 5,2 & 5,4 \\
\hline 10 & 10 & 10,9 & 12 \\
\hline 15 & 15 & 17,3 & 20 \\
\hline $\mathbf{2 0}$ & 20 & 24,3 & 29,8 \\
\hline 25 & 25 & 32 & 41,6 \\
\hline 30 & 30 & 40,6 & 56,1 \\
\hline 35 & 35 & 50 & 73,7 \\
\hline 40 & 40 & 60,4 & 95 \\
\hline
\end{tabular}

Source: Pd-T14-2003

\begin{tabular}{|c|c|c|c|}
\hline $\begin{array}{l}\text { Age of } \\
\text { Plan } \\
\text { (Year) }\end{array}$ & \multicolumn{3}{|c|}{ Growth Rate (i) Yearly (\%) } \\
\hline & 6 & 8 & 10 \\
\hline 5 & 5,6 & 5,9 & 6,1 \\
\hline 10 & 13,2 & 14,5 & 15,9 \\
\hline 15 & 23,3 & 27,2 & 31,8 \\
\hline $\mathbf{2 0}$ & 36,8 & 45,8 & 57,3 \\
\hline 25 & 54,9 & 73,1 & 98,3 \\
\hline 30 & 79,1 & 113,3 & 164,5 \\
\hline 35 & 111,4 & 172,3 & 271 \\
\hline 40 & 154,8 & 259,1 & 442,6 \\
\hline
\end{tabular}

Source: Pd-T14-2003
Tabel 5. Axis plan repetition calculation

\begin{tabular}{|c|c|c|c|c|}
\hline $\begin{array}{c}\text { Axis } \\
\text { Type }\end{array}$ & $\begin{array}{c}\text { Axis } \\
\text { Load } \\
\text { (tons } \\
\text { ) }\end{array}$ & $\begin{array}{c}\text { Numbe } \\
\text { r of } \\
\text { Axes }\end{array}$ & $\begin{array}{c}\text { Proportio } \\
\text { n of } \\
\text { Expense } \\
\text { s }\end{array}$ & $\begin{array}{c}\text { Proport } \\
\text { ion of } \\
\text { Axis }\end{array}$ \\
\hline (1) & $\mathbf{( 2 )}$ & $\mathbf{( 3 )}$ & $\mathbf{( 4 )}$ & $\mathbf{( 5 )}$ \\
\hline STRT & 6 & 5 & 0,054 & 0,72 \\
\hline & 5 & 13 & 0,141 & 0,72 \\
\hline & 4 & 28 & 0,304 & 0,72 \\
\hline & 3 & 18 & 0,196 & 0,72 \\
\hline & 2 & 28 & 0,304 & 0,72 \\
\hline Total & & $\mathbf{9 2}$ & $\mathbf{1 , 0 0}$ & \\
\hline STRG & 8 & 8 & 0,615 & 0,24 \\
\hline & 5 & 5 & 0,385 & 0,24 \\
\hline Total & & $\mathbf{1 3}$ & $\mathbf{1 , 0 0}$ & \\
\hline STdR & 14 & 5 & 1,00 & 0,04 \\
G & & & & \\
\hline Total & & $\mathbf{5}$ & $\mathbf{1 , 0 0}$ & \\
\hline
\end{tabular}

\begin{tabular}{|c|c|c|}
\hline \multirow[t]{2}{*}{ Axis Type } & $\begin{array}{l}\text { Traffic } \\
\text { Plan }\end{array}$ & $\begin{array}{l}\text { Repetition } \\
\text { that occurs }\end{array}$ \\
\hline & (6) & $(7)=(4) \times(5) \times(6)$ \\
\hline \multirow[t]{5}{*}{ STRT } & $0,75 \times 10^{5}$ & $0,29 \times 10^{4}$ \\
\hline & $0,75 \times 10^{5}$ & $0,76 \times 10^{4}$ \\
\hline & $0,75 \times 10^{5}$ & $1,64 \times 10^{4}$ \\
\hline & $0,75 \times 10^{5}$ & $1,05 \times 10^{4}$ \\
\hline & $0,75 \times 10^{5}$ & $1,64 \times 10^{4}$ \\
\hline \multicolumn{3}{|l|}{ Total } \\
\hline \multirow[t]{2}{*}{ STRG } & $0,75 \times 10^{5}$ & $1,10 \times 10^{4}$ \\
\hline & $0,75 \times 10^{5}$ & $1,69 \times 10^{4}$ \\
\hline \multicolumn{3}{|l|}{ Total } \\
\hline STdRG & $0,75 \times 10^{5}$ & $0,03 \times 10^{4}$ \\
\hline \multicolumn{3}{|l|}{ Total } \\
\hline Kun & latif & $7,47 \times 10^{4}$ \\
\hline
\end{tabular}

Source: Analysis results

Based on Table. 5 above it can be seen that the values: Proportion of the bed in column 4 is obtained by the equation of division between the number of axes and the total number of STRT, STRG, or STdRG

with the following examples for STRT:

$$
\begin{aligned}
& \frac{\text { Axis in total }}{\text { Total STRT }} \\
& =5 / 92=0.054
\end{aligned}
$$

The proportion of axes in column 5 is obtained by the equation of division between the total number of axes and the number of axes based on the load with the following example:

For STRT axis proportion $=92 / 128=0.72$

JSK value of $0.747 \times 10^{5}$ with tensile strength of 4.0 Mpa, subgrade CBR of $4 \%$, Effective CBR of $27 \%$ so that the estimated thickness of the concrete slab of $15 \mathrm{~cm}$ can be seen that the total fatigue that occurs $<100 \%$ can be concluded calculation is sufficient and $15 \mathrm{~cm}$ plate thickness can be used. 


\subsection{Reinforcement planning}

Reinforcement Planning is used based on the data obtained:

Plate friction coefficient with foundation $(\mu)=1.3$

MR Modulus Elastic Connection distance $(\mathrm{L})=10$ $\mathrm{m}$

Plate Thickness $(\mathrm{h})=0.15 \mathrm{~m}$

Steel Tensile Voltage (fs) $=4.0$

$\mathrm{MPa}$

Concrete Quality (fc) $=40 \mathrm{~kg} /$

$\mathrm{cm}^{2}$

Steel $($ Ice) $=20000$

$\mathrm{kg} / \mathrm{cm}^{2}$

Steel Melt Voltage

(fy) $=3900 \mathrm{~kg} / \mathrm{cm}^{2}$

Modulus Elastic

Concrete $(\mathrm{Ec})=1400$

cfc

Concrete Specific Weight $=$

$2400 \mathrm{~kg} / \mathrm{cm}^{2}$

Concrete Tensile Strength (fct)

$0.4-0.5=20 \mathrm{~kg} / \mathrm{cm}^{2}$

Transverse Reinforcement

$$
\text { As } \quad=\frac{\mu \cdot \text { L.M.g.h }}{2 f S}
$$

Lengthening Reinforcement

$$
\mathrm{P}_{\mathrm{s}} \quad=\frac{1 f c \cdot(1,3-0,2, \mu)}{(f y-n \cdot f c)}
$$

Where As is the reinforcement area

Based on the data above, we obtained As $=95.64 \mathrm{~mm}^{2}$ with As $\min =0.1 \% \times 150 \times 1000=150$

As Need = Ps x $100 \times$ plate thickness, the reinforcement diameter can be determined by looking at the following Table:

Table 6 List of Reinforced Steel Section $\left(\mathrm{cm}^{2}\right)$

\begin{tabular}{|c|c|c|c|c|c|}
\hline $\mathbf{A}$ & $\mathbf{1}$ & $\mathbf{2}$ & $\mathbf{3}$ & $\mathbf{4}$ & $\mathbf{5}$ \\
\hline $\boldsymbol{\varnothing 8}$ & 0,5 & 1 & 1,5 & 2 & 2,5 \\
\hline $\boldsymbol{\varnothing} \mathbf{1 0}$ & 0,79 & $\mathbf{1 , 5 8}$ & 2,37 & 3,16 & 3,95 \\
\hline $\boldsymbol{\varnothing ~ 1 2}$ & 1,13 & 2,26 & 3,39 & 4,52 & 5,65 \\
\hline $\boldsymbol{\varnothing ~ 1 5}$ & 1,76 & 3,52 & 5,28 & 7,04 & $\mathbf{8 , 8 0}$ \\
\hline
\end{tabular}

\begin{tabular}{|c|c|c|c|c|}
\hline $\mathbf{A}$ & $\mathbf{6}$ & $\mathbf{7}$ & $\mathbf{8}$ & $\mathbf{9}$ \\
\hline $\boldsymbol{\varnothing ~ 8}$ & 3 & 3,5 & 4 & 4,5 \\
\hline $\boldsymbol{\varnothing ~ 1 0}$ & 4,74 & 5,53 & 6,32 & 7,1 \\
\hline $\boldsymbol{\varnothing ~ 1 2}$ & 6,78 & 7,91 & 9,04 & 10,11 \\
\hline $\boldsymbol{\varnothing ~ 1 5}$ & 10,56 & 12,32 & 14,08 & 15,84 \\
\hline
\end{tabular}

Based on Table 6, List of Reinforced Steel Area, and calculation of reinforcement above As need to be obtained for the longitudinal reinforcement used is 5D15-200 while for transverse reinforcement used 2D10-500mm. Can be described below:

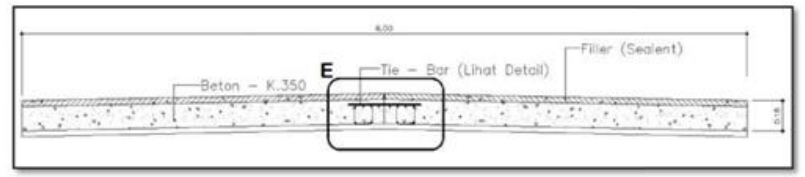

Fig. 4. Transverse reinforcement

(Source: analysis results)

\section{Conclusion}

The results of road improvement planning data analysis using rigid pavement on Munjul-Panimbang Banten road based on Pd-T-14-2003 guidelines can be summarized as follows:

a. The thickness of the concrete plate used to be able to withstand the load of vehicles passing on the MunjulPanimbang road segment is $15 \mathrm{~cm}$.

b. Longitudinal reinforcement per meter using 5D15 $\mathrm{mm}$ - 200 reinforcement rods, while transverse reinforcement per meter using 2D10 mm reinforcement rod $-500 \mathrm{~mm}$.

c. The planning of the thickness of the concrete plate and the diameter of the reinforcement of the concrete plate are in accordance with the guidelines of Pd-T14-2003 and have a level of security.

\section{References}

1. A. I. Manu, Departement of public Works Perkerasan Kaku (Rigid Pavement). Jakarta (1995)

2. Presiden Republik Indonesia, Undang-Undang Republik Indonesia Nomor 38 Tahun 2004 Tenntang Jalan, Sekertariat Negara Republik Indonesia (2004)

3. A. Fitri Nuryati Ningrum all, Perencanaan Peningkatan Jalan Tembus Jl.Anbrawa - Jl Soekarno Hata Batwen, Semarang, Jurnal of Civil Engineering journal Vol 4 No. 1 UNDIP, Semarang (2015)

4. Department of Housing and Regional Infrastructure, Pedoman Kontruksi dan Bangunan Pelaksanaan Pekerjaan Jalan Beton Semen. Jakarta (2002)

5. PU Research and Development Agency, Departement of public Works, Pedoman Pelaksanaan Pekejaan Beton Untuk Jalan dan Jembatan. Jakarta (2005)

6. Directorate General of Highways (2003), Perencanaan Perkerasan Jalan Beton Semen (Pd T14-2003)

7. Presiden Republik Indonesia, Undang-Undang Republik Indonesia Nomor 34 Tahun 2006 Tenntang Jalan, Sekertariat Negara Republik Indonesia (2006)

8. Indonesian Reinforced Concrete Regulatory Renewal Committee, Peraturan Beton Bertulang Indonesia 1971 N.I. - 2, Departement of public Works and electric power, Directorate General Ciptakarya, Directorate of Investigation Building Problems, Bandung (1971)

9. S. Sukirman, "Dasar-dasar Perencanaan Geometrik Jalan”, Nova Publiser, Bandung (1999) 